
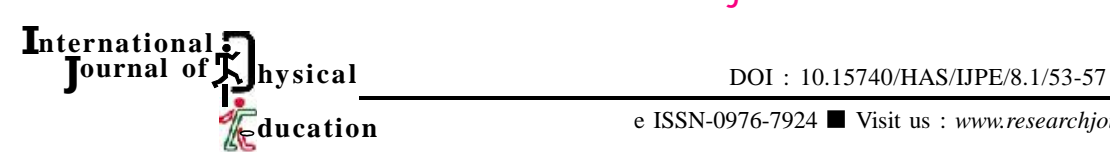

e ISSN-0976-7924 Visit us : www.researchjournal.co.in

A Case Study

Volume 8 | Issue 1 | April, 2015 | 53-57

\title{
Legal liabilities of injuries occur in sports in Indian conditions
}

\section{UMESH RATHI}

Author for correspondence

UMESH RATHI

Department of Physical Education,

Arts and Science College, Kurha,

AMRAVATI (M.S.) INDIA

Email: umeshrathisir@gmail.com

Received : 25.07.2014; Accepted : 22.03.2015

\section{-ABSTRACT}

The purpose of this study to survey legal liabilities of injuries occurs in sports in Indian conditions. Human body is most beautiful as well as the most complex thing nature created. If injury occurs to sports person that compel the sportsman to leave the sport.The liability of injuries that occur to sportsman on whom it lies. Nobody take the legal liability to treat the injuries and rehabilitate the players. The scholar made the survey about any rule to find out the legally responsibility. School and college, educational institutes were immune to law suits. Therefore the students of educational institutes were not getting compensation for injuries. It was also observed that 60 to 75 per cent injuries to boy and 40 to 50 per cent injuries occur on play field during physical education class.

- KEY WORDS : Legal liability, Injury, Indian conditions, Sports

- HOW TO CITE THIS PAPER : Rathi, Umesh (2015). Legal liabilities of injuries occur in sports in Indian conditions. Internat. J. Phy. Edu., 8 (1) : 53-57. 